\title{
Environmental factors restrict the invasion process of Limnoperna fortunei (Mytilidae) in the Neotropical region: A case study from the Andean tributaries
}

\author{
Gustavo Darrigran $^{1 *}$, Cristina Damborenea ${ }^{1}$, Edmundo C. Drago $^{2}$, Ines Ezcurra de Drago $^{2}$ \\ and Aldo Paira ${ }^{2}$ \\ ${ }^{1}$ CONICET, División Zoología Invertebrados, Museo de La Plata, FCNyM-UNLP, Paseo del Bosque, 1900 La Plata, Argentina \\ 2 Instituto Nacional de Limnología, CONICET-UNL, Ciudad Universitaria - Paraje "El Pozo", 3000 Santa Fe, Argentina
}

Received 24 September 2010; Accepted 18 April 2011

\begin{abstract}
The golden mussel Limnoperna fortunei was introduced into Argentina in 1991 and has since been spreading through the Plata and Guaíba basins at a rate of $240 \mathrm{~km}$.year ${ }^{-1}$. To assess their ability to invade the Andean tributaries of the Plata Basin (Pilcomayo, Bermejo and Salado del Norte rivers), their current range was assessed and related to the abiotic parameters of sites where they were present and absent. These data were then compared with their known tolerances to identify possible barriers to invasion. Outputs suggested that three environmental parameters are barriers to invasion: salinity and river flow intermittence in different sectors of the rivers Pilcomayo and Salado del Norte, and concentration of suspended sediments in the Bermejo River and in the upper reaches of the Salado del Norte and Pilcomayo rivers. The importance of these findings is discussed in relation to using environmental data to infer the invasion possibilities and the utility of environmental data to better understand invasion patterns and processes.
\end{abstract}

Key words: Abiotic parameters / barrier dispersion / bioinvasion / freshwater / golden mussel / Limnoperna sp.

\section{Introduction}

A consequence of globalization is the change of natural environments and species communities. With the exception of climate change, biological invasions probably have received more attention in recent years than any other ecological topic. In the past 10 years, a large number of papers, books, workshops and symposia addressing biological invasions were made (Davis, 1999). Geographic scale, frequency, and number of native and non-native species involved have increased dramatically over the past few decades (Emerton and Howard, 2008). Currently, introduced species are a main driver of biodiversity loss after habitat destruction (IUCN, 2000). Their negative impacts affect three essential components of biodiversity: landscape, species and genetic structure (Carlton, 1996). A further issue is the global biotic homogenization that arises from increased introductions as native and endemic species become displaced, leading to an increased similarity of biotic communities over time and space (Rahel, 2002).

The term "invasiveness" refers to the ability of an introduced species to invade a given habitat and

\footnotetext{
*Corresponding author: invasion@fcnym.unlp.edu.ar
}

"invasibility" to the characteristics of a potential new habitat. In combination, these help determine the chances of establishment and dispersal of the introduced species (Marco et al., 2002). Thus, the ability of an introduced species to become invasive is determined through a complex interaction of the characteristics of the species, the native communities and the receiving habitat (Marco et al., 2002). To help prevent invasions, preventative and control measures may be used: predictive risk assessment, early detection, quick response and public education (Kluza and McNyset, 2005). Despite their ability to minimize the biotic homogenization of regions, there has been no formal implementation of these tools in South America (Darrigran et al., 2004) and instead invasions are dealt with in a reactive manner, i.e., when the species are already dispersing and impacting (Darrigran and Damborenea, 2006).

Information on native and introduced biodiversity in the Neotropical region is scarce and often only found in cryptic literature (Orenzans et al., 2002). Under these circumstances, the description of species abundance distribution (SAD) within a community becomes important in understanding biodiversity patterns (McGill et al., 2007). In 1991, golden mussel Limnoperna fortunei 
(Dunker 1857) was found while studying SAD in the Río de la Plata estuary (Pastorino et al., 1993). This species soon started to rapidly disperse at a rate of $240 \mathrm{~km}$.year ${ }^{-1}$ (Darrigran, 2002) and became a serious macrofouling organism (Darrigran, 2010; Darrigran and Damborenea, 2011), and its impact may become as significant as that of the invasive zebra mussel Dreissena polymorpha (Pallas 1771) in North America (Claudi and Mackie, 1994). Indeed, the invasive potential of L. fortunei is revealed by its sharing of a number of biological characteristics with D. polymorpha (Morton, 1977), including its freeswimming planktonic larvae (Darrigran et al., 2007), byssal filaments for attachment to hard substrates, high resistance to air exposure (Montalto and Ezcurra de Drago, 2003; Darrigran et al., 2004) and high reproductive potential (Darrigran et al., 2003). Since L. fortunei was introduced in South America, there have been attempts to understand the pattern of invasion and the rate of dispersion in order to better comprehend its bioinvasion processes (Darrigran, 2002; Darrigran and Damborenea, 2005; Boltovskoy et al., 2006). Given the likelihood that L. fortunei will eventually invade North America and Europe, such studies may have global significance (Ricciardi, 1998; Darrigran and Pastorino, 2004; Darrigran et al., 2007; Karatayev et al., 2007a; Oliveira et al., 2010a, 2011).

The rate of spread of introduced species depends on spatial scale and the extent to which both abiotic parameters and human activities accelerate or inhibit this process. A hierarchy of spatial scales exists, covering the range global, continental, regional, local (smaller units), water-body and habitat (Karatayev et al., 2007b). While this spatial hierarchy is useful for predicting potential dispersion of invading bivalves, erroneous predictions are possible if the invasibility of a spatial higher scale is appraised that disregards the invasibility power of the immediately lower spatial hierarchy and the invasiveness of the species considered. On the basis that a prediction of the potential distribution of invasive species can be made at different spatial scales of resolution (Karatayev et al., 2007b), the invasiveness of L. fortunei was considered in the Pilcomayo, Bermejo and Salado del Norte rivers, Argentina. The aim was to investigate the distribution of L. fortunei in these rivers and relate their presence and absence to a series of environmental and physicochemical parameters to ascertain whether any of these were acting as effective barriers to the invasion.

\section{Material and methods}

\section{Study area}

The sampling of L. fortunei in the Pilcomayo and Bermejo rivers, the upper basin of the Salado del Norte River, and in the Lower Paraguay River, covered its present range and also non-invaded areas. This area drains about $21 \%$ of the Plata Basin $\left(3140000 \mathrm{~km}^{2}\right.$ ) (UNL, 2005). The sampled rivers cross different ecoregions. Their headwaters lie mainly in the arid/semiarid or in the wet Andes and flow downstream through dry and wet areas of the Chaco Plain. These strong changes suggest a vision of the river as a "discontinuum", highlighting the nonuniform or patchy distribution of habitats and emphasizing habitat heterogeneity at the scale of meters-kilometers (Frissel et al., 1986; Poff, 1997; Benda et al., 2004). The characteristics of each river are as follows.

\section{Pilcomayo River}

This flows along $1600 \mathrm{~km}$, draining a $281000 \mathrm{~km}^{2}$ basin with variable geomorphological, hydrological and hydrochemical characteristics. Considering the characteristics of this river, the key factors for this research are (1) river regime (Haines et al., 1988; Roche et al., 1989), (2) geomorphological channel characteristics (Martín Vide et al., 2007), (3) amount and deposition rate of suspended sediments and discharge rate variations (Roche et al., 1989; Amarilla and Amsler, 2005; Martín Vide et al., 2007), (4) stream-flow variation (EVARSA, 2000; Goniadzki et al., 2007; Martín Vide et al., 2007), and (5) water salinity (Cordini, 1947).

\section{Bermejo River}

This system has a catchment area of $133000 \mathrm{~km}^{2}$ and a length of $1800 \mathrm{~km}$ (Fig. 1) (Soldano, 1947). It is perennial despite the moderate early summer regime (Haines et al., 1988), with flow peaks in summer and minimum levels in late autumn, winter and early spring. The most important characteristics of this river are the large suspended sediment load (more than $150 \times 10^{6}$ t.year $^{-1}$ ) (Drago and Amsler, 1988; Amsler and Drago, 1999) and a low salinity (less than 0.4 g. $\mathrm{L}^{-1}$ ), from its headwaters to the mouth.

\section{Salado del Norte River}

Its basin covers $247000 \mathrm{~km}^{2}$, being the longest river in Argentina with $2000 \mathrm{~km}$ length (Fig. 1). Drought phases occur because the river course runs across the "arid diagonal" (Bonetto, 1994) and also because of its allochtonous character, high rates of infiltration, and diversion and damming of its flow for irrigation purposes. The upper segment carries high sediment loads (Drago and Paira, 1997). There are also changes in salinity; the headwater streams usually yield low salinities $\left(<0.5\right.$ g. $\left.\mathrm{L}^{-1}\right)$, increasing to $1.3-96.0$ g. $\mathrm{L}^{-1}$ in the middle and lower segments of the Salado del Norte River (Drago and Quirós, 1996; Drago and Paira, 1997). Along its lower segment the river changes its intermittent flow regime and loses its allochtonous character due to the confluence of the Calchaquí River. The input of this river and of several other tributaries (ranges from 2 to 96 g. $\mathrm{L}^{-1}$ ) increases its salinity, determining a mean salinity of 6 g.L ${ }^{-1}$ for the Lower Salado del Norte River (Drago and Paira, 1997). 


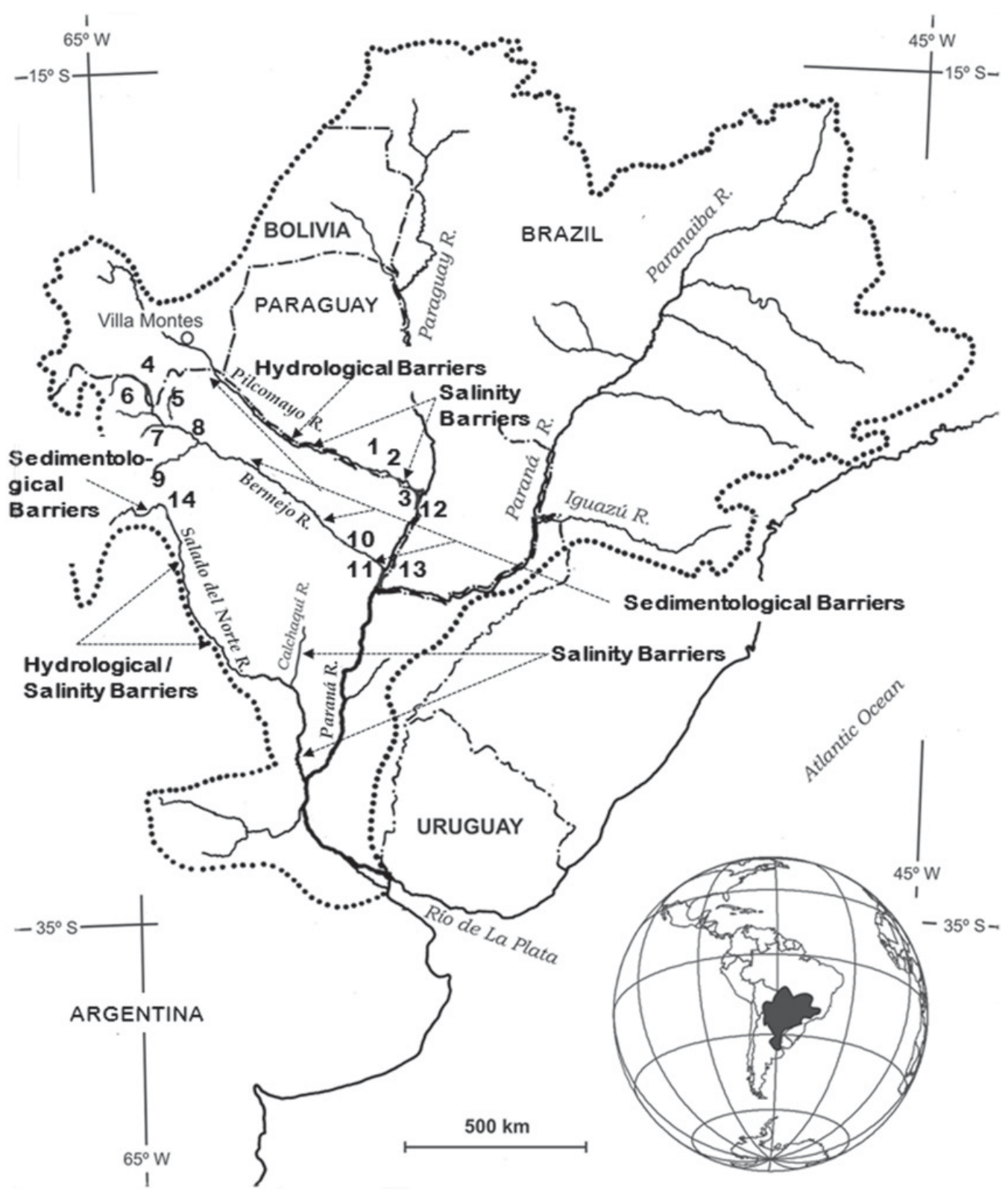

Fig. 1. The Plata Basin and the sampling stations in the Pilcomayo (1, 2, 3), Bermejo (4-11), Lower Paraguay (12, 13) and Salado del Norte (14) rivers. Locations of the hydrological, sedimentological and salinity barriers avoiding the invasion of the L. fortunei in the studied rivers are indicated.

\section{Sampling regime}

Across the rivers, 14 selected sites were sampled during a low-water period from 15 to 25 November 2005 (Fig. 1, Table 1). The presence/absence of adults of L. fortunei in sampling sites was determined qualitatively by visual inspection in the available substrates (the aquatic vegetation, submerged dredge-out blocks, rocky exposures, and built in-stream structures along the banks and riverbed), for a period of at least $60 \mathrm{~min}$, conducted by two researchers. A quantitative sampling of larvae was also performed, filtering $100 \mathrm{~L}$ through to $35 \mu \mathrm{m}$ mesh. The absence of larvae in the samples was interpreted as the absence of a reproducing population since the survey was made in the golden mussel breeding season.

At each sampling site (SS), the following environmental factors were also determined: elevation (m a.s.1.), water velocity, water and air temperature, salinity (water checker Hach 44600), pH, transparency (Secchi disc), suspended sediments (size $<62 \mu \mathrm{m}$ ), suspended organic matter, dissolved organic matter, dissolved oxygen and calcium (as $\mathrm{Ca}^{2+}$ ). These factors were then compared with the tolerance limits mentioned previously for L. fortunei (Table 2). The suspended sediment levels were obtained by filtering $5 \mathrm{~L}$ of water with a vacuum pump and using a Chamberland filter (retention capacity $\geq 1 \mu \mathrm{m}$ ). 
Table 1. Location of the sampling stations (the numbers correspond to Fig. 1).

\begin{tabular}{cll}
\hline No. & \multicolumn{1}{c}{ Sampling stations } & Geographic coordinates \\
\hline 1 & Lower Pilcomayo River, general Belgrano-Bruguez international bridge (Formosa) & $24^{\circ} 44^{\prime} 54^{\prime \prime} \mathrm{S}-58^{\circ} 50^{\prime} 00^{\prime \prime} \mathrm{W}$ \\
2 & Laguna Blanca, Río Pilcomayo National Park (Formosa) & $24^{\circ} 10^{\prime} 16^{\prime \prime} \mathrm{S}-58^{\circ} 07^{\prime} 51^{\prime \prime} \mathrm{W}$ \\
3 & Lower Pilcomayo River, Clorinda (Formosa) & $24^{\circ} 15^{\prime} 18^{\prime \prime} \mathrm{S}-57^{\circ} 43^{\prime} 41^{\prime \prime} \mathrm{W}$ \\
4 & Upper Bermejo River, Aguas Blancas (Salta) & $22^{\circ} 43^{\prime} 53^{\prime \prime} \mathrm{S}-64^{\circ} 21^{\prime} 08^{\prime \prime} \mathrm{W}$ \\
5 & Seco River (Salta) & $23^{\circ} 01^{\prime} 34^{\prime \prime} \mathrm{S}-63^{\circ} 55^{\prime} 01^{\prime \prime} \mathrm{W}$ \\
6 & Iruya-Pescado River (Salta) & $22^{\circ} 57^{\prime} 56^{\prime \prime} \mathrm{S}-64^{\circ} 21^{\prime} 55^{\prime \prime} \mathrm{W}$ \\
7 & San Francisco River (Salta) & $23^{\circ} 21^{\prime} 36^{\prime \prime} \mathrm{S}-64^{\circ} 10^{\prime} 49^{\prime \prime} \mathrm{W}$ \\
8 & Upper Bermejo River, M. Elordi (Salta) & $23^{\circ} 14^{\prime} 58^{\prime \prime} \mathrm{S}-64^{\circ} 08^{\prime} 27^{\prime \prime} \mathrm{W}$ \\
9 & Del Valle River, Las Lajitas (Salta) & $24^{\circ} 42^{\prime} 10^{\prime \prime} \mathrm{S}-64^{\circ} 11^{\prime} 21^{\prime \prime} \mathrm{W}$ \\
10 & Lower Bermejo River, El Colorado (Formosa) & $26^{\circ} 20^{\prime} 03^{\prime \prime} \mathrm{S}-59^{\circ} 21^{\prime} 43^{\prime \prime} \mathrm{W}$ \\
11 & Lower Bermejo River, L. V. Mansilla (Formosa) & $26^{\circ} 39^{\prime} 36^{\prime \prime} \mathrm{S}-58^{\circ} 38^{\prime} 00^{\prime \prime} \mathrm{W}$ \\
$12^{*}$ & Paraguay River, Puerto Pilcomayo (Formosa) & $25^{\circ} 22^{\prime} 00^{\prime \prime} \mathrm{S}-57^{\circ} 39^{\prime} 12^{\prime \prime} \mathrm{W}$ \\
$13^{*}$ & Lower Paraguay, Puerto Las Palmas (Chaco) & $27^{\circ} 07^{\prime} 10^{\prime \prime} \mathrm{S}-58^{\circ} 38^{\prime} 42^{\prime \prime} \mathrm{W}$ \\
14 & Upper Salado del Norte River, J. V. González (Salta) & $25^{\circ} 20^{\prime} 57^{\prime \prime} \mathrm{S}-64^{\circ} 03^{\prime} 02^{\prime \prime} \mathrm{W}$ \\
\hline
\end{tabular}

* Presence of stable populations of L. fortunei.

Table 2. Tolerance limit values referred to L. fortunei.

\begin{tabular}{|c|c|c|}
\hline Parameter & & Reference \\
\hline \multirow[t]{2}{*}{ Upper salinity } & $\leq 3$ g. $\mathrm{L}^{-1}$ & $\begin{array}{l}\text { Deaton et al. (1989), Capítoli and Bemvenuti (2004), } \\
\text { Darrigran and Damborenea (2005), } \\
\text { Angonesi et al. (2008), Capítoli et al. (2008) }\end{array}$ \\
\hline & $<5$ g. $\mathrm{L}^{-1}$ & Barbosa and Melo (2009) \\
\hline \multirow[t]{3}{*}{ Lower temperature } & $12^{\circ} \mathrm{C}$ & dos Santos et al. (2008) \\
\hline & $5^{\circ} \mathrm{C}$ & Oliveira et al. (2010a) \\
\hline & $0{ }^{\circ} \mathrm{C}$ & Choi and Kim (1985); Choi and Shin (1985) \\
\hline \multirow[t]{3}{*}{ Upper temperature } & $31.8^{\circ} \mathrm{C}$ & Oliveira et al. (2006) \\
\hline & $33^{\circ} \mathrm{C}$ & Darrigran and Damborenea (2005) \\
\hline & $35^{\circ} \mathrm{C}$ & Oliveira et al. (2011) \\
\hline \multirow[t]{2}{*}{ Upper pH } & 7.22 & Marçal and Callil (2008) \\
\hline & 7.8 & Oliveira et al. (2011) \\
\hline \multirow[t]{3}{*}{ Lower $\mathrm{pH}$} & 6.3 & Marçal and Callil (2008) \\
\hline & 6.2 & Darrigran (2002), dos Santos et al. (2008) \\
\hline & 6.0 & Oliveira et al. (2010a) \\
\hline Upper calcium & $11.60 \mathrm{mg} . \mathrm{L}^{-1}$ & Oliveira et al. (2006) \\
\hline \multirow[t]{2}{*}{ Lower calcium } & $1.0 \mathrm{mg} \cdot \mathrm{L}^{-1}$ & Oliveira et al. (2010a, 2010b) \\
\hline & $3.96 \mathrm{mg} . \mathrm{L}^{-1}$ & Darrigran and Damborenea (2005) \\
\hline Lower oxygen & $0.2 \mathrm{mg} . \mathrm{L}^{-1}$ & Oliveira et al. (2006) \\
\hline Upper oxygen & $11.33 \mathrm{mg} . \mathrm{L}^{-1}$ & dos Santos et al. (2008) \\
\hline Lower suspended sediment concentration & 0.0001 g. $\mathrm{L}^{-1}$ & dos Santos et al. (2008) \\
\hline Upper suspended sediment concentration & 0.214 g. $\mathrm{L}^{-1}$ & dos Santos et al. (2008) \\
\hline \multirow[t]{2}{*}{ Air exposition (elevated humidity environment) } & $168 \mathrm{~h}$ & Darrigran et al. (2004) \\
\hline & $72-276 \mathrm{~h}$ & Montalto and Ezcurra de Drago (2003) \\
\hline Depth & $40 \mathrm{~m}$ & Darrigran et al. (2007) \\
\hline \multirow[t]{2}{*}{ Lower transparency } & $0.156 \mathrm{~m}$ & Marçal and Callil (2008) \\
\hline & $0.1 \mathrm{~m}$ & Oliveira et al. (2011) \\
\hline Upper water velocity & $1.1 \mathrm{~m} \cdot \mathrm{s}^{-1}$ & Oliveira et al. (2011) \\
\hline
\end{tabular}

Samples were oven-dried $\left(105^{\circ} \mathrm{C}\right)$ and then weighed (precision $=0.1 \mathrm{mg}$ ). Suspended organic matter was obtained by ignition in a muffle $\left(550^{\circ} \mathrm{C}\right.$ for $\left.20 \mathrm{~min}\right)$ and weighed (precision $=0.1 \mathrm{mg})(\mathrm{APHA}, 1985)$. For $\mathrm{Ca}^{2+}$ (mg. $\mathrm{L}^{-1}$ ) determinations, samples were treated according to EPA 600/R-94/111 - Method 200.2. Measurements were made by flame atomization, using the calibration curve method with aqueous standards and a Perkin Elmer Analyst 800 spectrometer.

\section{Data analysis}

A non-metric multi-dimensional scaling method was applied to relate environmental data and the presence/ absence of $L$. fortunei in the sampled stations; the stress value was calculated to measure the goodness of fit using PAST Paleontological Statistics 2.07 (Hammer et al., 2001). Environmental data of a sampling station in the Paraná River $\left(32^{\circ} 39^{\prime} \mathrm{S}-60^{\circ} 44^{\prime} \mathrm{W}\right.$; Table 3, PR), 
Table 3. Physical and chemical parameters of the aquatic environments measured during the field trip (m a.s.l, elevation; WV, water velocity; AT, air temperature; WT, water temperature; T, transparency; Susp. sed, suspended sediment; SOM, suspended organic matter; SAL, salinity; DOM, dissolved organic matter; DO, dissolved oxygen and $\mathrm{Ca}^{2+}$. Sampling stations numbers correspond to Figure 1 and Table 1. PR: control sample for Timbúes, Río Paraná, Santa Fe, Argentina.

\begin{tabular}{|c|c|c|c|c|c|c|c|c|c|c|c|c|}
\hline $\begin{array}{l}\text { Sampling } \\
\text { stations } \\
\text { (SS) }\end{array}$ & m a.s.l. & $\mathrm{WV}\left(\mathrm{m} . \mathrm{s}^{-1}\right)$ & $\operatorname{AT}\left({ }^{\circ} \mathrm{C}\right)$ & WT $\left({ }^{\circ} \mathrm{C}\right)$ & $\mathrm{T}(\mathrm{m})$ & $\begin{array}{l}\text { Susp. sed. } \\
\left(\text { g. } L^{-1}\right)\end{array}$ & $\begin{array}{c}\mathrm{SOM} \\
\left(\mathrm{g} . \mathrm{L}^{-1}\right)\end{array}$ & $\begin{array}{c}\text { SAL } \\
\left(\mathrm{g} . \mathrm{L}^{-1}\right)\end{array}$ & $\begin{array}{c}\text { DOM } \\
\left(\text { g.L } L^{-1}\right) \\
\end{array}$ & $\begin{array}{c}\text { DO } \\
\left(\mathrm{mg} . \mathrm{L}^{-1}\right) \\
\end{array}$ & $\mathrm{pH}$ & $\begin{array}{c}\mathrm{Ca}^{2+} \\
\left(\mathrm{mg} \cdot \mathrm{L}^{-1}\right) \\
\end{array}$ \\
\hline 1 & 99 & 0.43 & 31.0 & 28.3 & Bed & 1.7051 & 0.0604 & 19.6486 & 0.7358 & 9.3 & 8.3 & 258.0 \\
\hline 2 & 88 & & 32.0 & 28.5 & 0.20 & 0.1263 & 0.0104 & 0.1034 & 0.0164 & 6.0 & 7.0 & 0.92 \\
\hline 3 & 61 & 0.10 & 28.0 & 28.8 & 0.29 & 0.1221 & 0.0061 & 0.8402 & 0.0404 & 6.0 & 6.5 & 17.0 \\
\hline 4 & 408 & 0.65 & 24.0 & 25.8 & 0.025 & 4.5706 & 0.1842 & 0.2980 & 0.0764 & 7.8 & 7.5 & 11.0 \\
\hline 5 & 337 & 0.62 & 25.0 & 26.1 & 0.015 & 7.0625 & 0.2434 & 1.3040 & 0.0554 & 8.4 & 8.4 & 38.0 \\
\hline 6 & 355 & 0.50 & 23.5 & 27.7 & Bed & 0.0165 & 0.0016 & 0.1906 & 0.0052 & 8.8 & 8.2 & 47.0 \\
\hline 7 & 311 & 0.62 & 25.0 & 27.7 & Bed & 0.2049 & 0.0088 & 0.6298 & 0.0412 & 8.9 & 8.4 & 60.0 \\
\hline 8 & 301 & 0.91 & 30.0 & 28.7 & 0.18 & 0.4799 & 0.0079 & 0.2524 & 0.0064 & 6.9 & 7.7 & 34.0 \\
\hline 9 & 470 & 2.50 & 24.0 & 26.5 & 0.19 & 0.5599 & 0.0238 & 0.3627 & 0.0118 & 7.6 & 7.0 & 65.0 \\
\hline 10 & 91 & 0.17 & 31.0 & 31.6 & 0.31 & 0.1078 & 0.0194 & 0.3110 & 0.0656 & 11 & 8.3 & 42.0 \\
\hline 11 & 67 & 0.14 & 36.2 & 31.5 & 0.44 & 0.1411 & 0.0114 & 0.3210 & 0.0026 & 12 & 8.1 & 33.0 \\
\hline 12 & 68 & 0.62 & 33.8 & 30.0 & 0.38 & 0.1448 & 0.0141 & 0.1034 & 0.0602 & 7.2 & 6.3 & 2.0 \\
\hline 13 & 59 & 0.50 & 33.0 & 29.7 & 0.40 & 0.0880 & 0.2480 & 0.1036 & 0.0622 & 6.8 & 6.2 & 2.0 \\
\hline 14 & 357 & 0.71 & 24.1 & 26.2 & Bed & 0.0657 & 0.0044 & 0.3108 & 0.0068 & 7.5 & 7.0 & 46.0 \\
\hline PR & 60 & 0.56 & 20.0 & 18.9 & 0.39 & 0.039 & 0.131 & 0.200 & 0.0612 & 6.95 & 7.97 & 7.5 \\
\hline
\end{tabular}

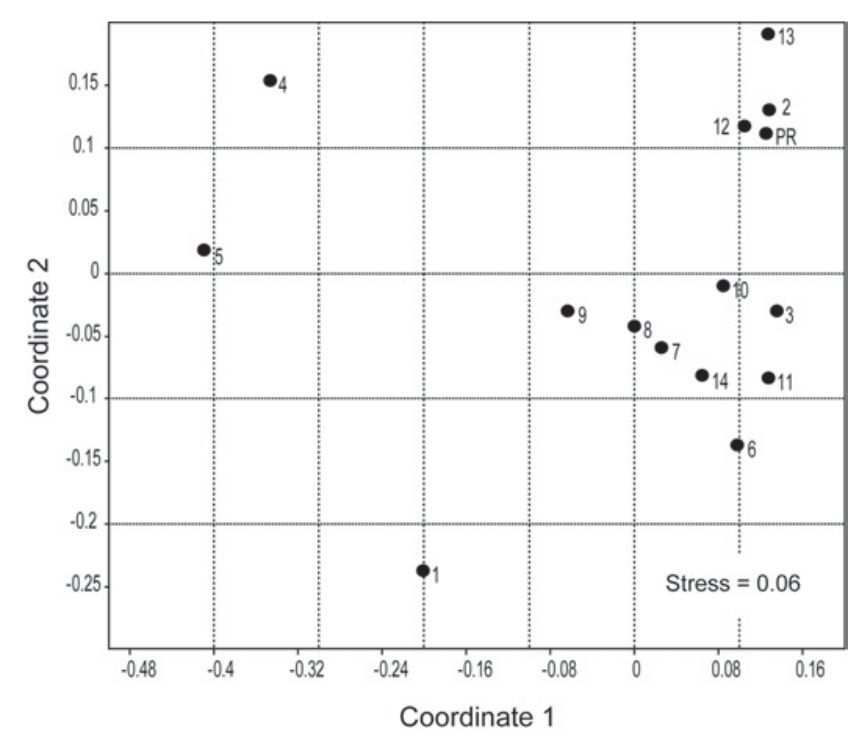

Fig. 2. Non-metric multi-dimensional scaling of 14 sampling stations and a control station (PR).

in which L. fortunei has stable populations, were incorporated into the analysis.

\section{Results}

L. fortunei was found at two sampling stations only, i.e., Puerto Pilcomayo (SS 12) and Puerto Las Palmas (SS 13), both on the Lower Paraguay River (Table 1). Mean larvae densities in these sampling stations were 33.18 (SD: 1.78) and 15.83 (SD: 3.87) larvae.L $^{-1}$, respectively. Adult density was 45000 ind. $^{-2}$ in SS 12 . Field surveys of the rivers and associated aquatic habitats, together with measurements of the environmental variables, reveal high hydrosedimentological and chemical variability between the sampled sites (Table 3 ).

The multi-dimensional scaling revealed that the sampling stations could be arranged into three groups (Fig. 2). The first includes the SS 1, 4 and 5, with extreme environmental characteristics (e.g., high concentrations of suspended sediment and salinity). The second links two stations with presence of L. fortunei (SS 12 and 13), the Parana River station (PR) used as control, environmental characteristics optimal for the development of stable populations of the golden mussel, and SS 2 for Laguna Blanca at Río Pilcomayo National Park. The third group encompasses the other stations (Table 3 ).

SS 1 in the Lower Pilcomayo had a salinity of $19.65{\mathrm{~g} . \mathrm{L}^{-1}}^{-1}$ at the time of sampling. However, the remaining sites showed salinity values lower than 3 g. $\mathrm{L}^{-1}$ (Table 3). The suspended sediment concentration in the Upper Bermejo River is more than 0.214 g. $\mathrm{L}^{-1}$ (SS 1, 4, 5, 8 and 9) and only one sample site (SS 7) showed a slightly lower value (Table 3). Localities with golden mussel populations on the Lower Paraguay River had values 0.1448 g. $\mathrm{L}^{-1}$ (SS 12) and 0.088 g.L ${ }^{-1}$ (SS 13). $\mathrm{Ca}^{2+}$ concentrations at the sampling sites ranged between 2.0 and $258.0 \mathrm{mg} . \mathrm{L}^{-1}$. The two sampling sites with populations of L. fortunei (SS 12 and 13) had the lowest $\mathrm{Ca}^{2+}$ concentration $\left(2.0 \mathrm{mg} . \mathrm{L}^{-1}\right)$. Water velocity was less than $1 \mathrm{~m} . \mathrm{s}^{-1}$ for most sampling stations (Table 3); only at SS 8 did it reach a value near $1 \mathrm{~m} . \mathrm{s}^{-1}\left(0.91 \mathrm{~m} . \mathrm{s}^{-1}\right)$ and at SS 9 it reached a higher value than $1 \mathrm{~m} . \mathrm{s}^{-1}\left(2.5 \mathrm{~m} . \mathrm{s}^{-1}\right)$. Dissolved oxygen concentration varied from 6 to $12 \mathrm{mg} . \mathrm{L}^{-1}$ and $\mathrm{pH}$ exceeded 8 at six of the locations sampled (Table 3 ). Transparency values were highly variable (from to see the bed in a very low depth rivers to $0.015 \mathrm{~m}$; Table 3 ). 


\section{Discussion}

The hydrological, sedimentological and chemical data, in conjunction with data on L. fortunei environmental tolerances taken from the literature (Table 2), were useful in assessing their ability to invade the Pilcomayo, Bermejo and Salado del Norte rivers upstream toward the Andes. The ordination analysis performed allows grouping all the sampling stations, including also sites that show the optimum environmental characteristics for the development of $L$. fortunei (SS 12, 13 and PR). This group included SS 2, which has appropriate environmental conditions for the development of the golden mussel. However, in this station, larvae, juveniles and adults were absent. This station is under the protection of National Park Service, which is largely responsible for administrating environmental laws and regulations (e.g., controlling the entry of exotic species), which would be acting as a barrier to stop the invasion. Also, two of the potential dispersion barriers to invasion are shown in Figure 2, where SS groups 1, 4 and 5, with high concentrations of suspended sediments and salinity, limit the spread of the golden mussel in the region (Table 2). Finally, according to Oliveira et al. (2011), the group with the remaining sampling stations has a combined effect of several of these and other environmental conditions, which limit the invasion of this species. Therefore, regardless of the rate of dispersal of $L$. fortunei in the Neotropical region, there appear to be three barriers that limit their dispersal and invasion. Analysis of the physicochemical parameters and hydrological characteristics of the sampled stations allowed identifying three barriers to dispersion of the golden mussel, i.e., salinity, suspended sediment concentration and flow intermittency (Figs. 1 and 2). These are discussed next.

\section{Salinity barrier}

The Lower Pilcomayo has a salt concentration range of 5-60 g. $\mathrm{L}^{-1}$, suggesting an input of high-salinity groundwater (Cordini, 1947). It appears as a limiting factor in Pilcomayo River (Fig. 1) $100 \mathrm{~km}$ upstream of its junction with the Paraguay River, where it presents a salinity of 19.65 g.L ${ }^{-1}$ (SS1; Table 3). Salinity is a serious threat to freshwater ecosystems, as has been demonstrated in coastal environments, due to the changes it produces in community structure (Gonçalves et al., 2007). Stable natural populations of this bivalve do not tolerate salinities above 3 g. $\mathrm{L}^{-1}$ (Darrigran, 2002; Barbosa and Melo, 2009). Experimental studies revealed that L. fortunei could live only over three weeks with a salt concentration of $6.8 \mathrm{~g} . \mathrm{L}^{-1}$ (Deaton et al., 1989).

Salinity is also a limiting barrier in the Salado del Norte River (Fig. 1). The Upper Salado del Norte River shows low salinities not above 0.5 g. $\mathrm{L}^{-1}$, while downstream it reaches salinities between 10 and 100 g.L ${ }^{-1}$ (Williams, 1981; Drago and Paira, 1997). In the lower end, near the confluence with the Middle Paraná River, the freshwater of the last river flows upstream about $10 \mathrm{~km}$ during exceptional floods. During the prolonged "El Niño" flood of 1997-1998, salinity of this sector dropped sharply from $3-4$ to $<1$ g. $\mathrm{L}^{-1}$. Because of the long period of flooding at that time (13 months), L. fortunei developed numerous metapopulations (Darrigran and Ezcurra de Drago, 2000; Ezcurra de Drago et al., 2006), which phased out when the usual salinity levels were restored.

\section{Sedimentological barrier}

The limiting factor for the settlement of L. fortunei in the Bermejo River appeared to be the high concentration of suspended sediment (Fig. 1). The average concentration is 6 g. $\mathrm{L}^{-1}$, but exceeded $40 \mathrm{~g} . \mathrm{L}^{-1}$ during floods (Drago and Amsler, 1988; Amsler and Drago, 1999). In the Upper Pilcomayo Basin, the concentration of suspended sediments is also one of the important factors that prevent the invasion of L. fortunei, with wash load percentages of $90 \%$ or more (Fig. 1); the average concentration is 24 g. $\mathrm{L}^{-1}$ (Martín Vide et al., 2007). Although salinity values in the Upper Pilcomayo River and in the first sector of the Middle Pilcomayo range between 0.1 and 0.5 g.L ${ }^{-1}$, the high concentration of suspended sediments prevents the invasion of this bivalve (40-60 g. $\mathrm{L}^{-1}$, Martín Vide, personal communication). Suspended sediment values in the Upper Salado del Norte River were 0.07 g. $\mathrm{L}^{-1}$ during low water periods (Table 3). The data show that the concentration values in this area are high (up to 20 g. $\mathrm{L}^{-1}$ ) during high water phases (Drago and Quirós, 1996; Drago and Paira, 1997). This concentration is a barrier to the settlement of the golden mussel in this river sector. However, along the middle sector of this river the concentrations drop sharply as sediment settles (1.00.07 g. $\mathrm{L}^{-1}$ ) (Drago and Paira, 1997). Information available on transparency tolerance limits of L. fortunei is scarce (Table 2). Oliveira et al. (2011) mentioned that L. fortune $i$ can live in an environment with a transparency of around $0.1-0.4 \mathrm{~m}$.

\section{Hydrological barrier}

Another key factor in the middle and lower segment of the Pilcomayo River was the high intermittence of water flow (Fig. 1; Cordini, 1947), with the river dry for over $360 \mathrm{~km}$, i.e., from the Esmeralda Tripartite International Landmark $\left(22^{\circ} 22^{\prime} \mathrm{S}-62^{\circ} 31^{\prime} \mathrm{W}\right.$; Fig. 1) to Cabo Primero Lugones $\left(24^{\circ} 17^{\prime} \mathrm{S}-59^{\circ} 49^{\prime} \mathrm{W}\right)$. This sector remained dry between 1983 and 1993; downstream from Estero Patiño $\left(24^{\circ} 04^{\prime} \mathrm{S}-59^{\circ} 50^{\prime} \mathrm{W}\right)$ it has been dry since 1973 up to the present (Martín Vide, personal communication). Intolerance of L. fortunei to dry conditions does not permit its surviving during the long drought phases of this river (Table 2). The Middle Salado del Norte River becomes intermittent and remains completely dry for long stretches (Drago and Paira, 1997). Furthermore, 
an additional limiting factor is the high salinity in the area (Fig. 1).

$\mathrm{Ca}^{2+}$ water content is one of the parameters affecting the distribution of freshwater mollusks (Sprung, 1987; Ramcharan et al., 1992; Vinogradov et al., 1993). Information on the minimal concentration of $\mathrm{Ca}^{2+}$ necessary for development of $L$. fortunei is scarce (Table 2), but available data suggest it ranges from 3 (Boltovskoy et al., 2006) to $3.96 \mathrm{mg} . \mathrm{L}^{-1}$ (Darrigran, 2002). Oliveira et al. (2010a, 2011) discussed that in the Pantanal, on the Paraguay River, L. fortunei lives in places where $\mathrm{Ca}^{2+}$ concentrations range from 1.0 to $6.0 \mathrm{mg} . \mathrm{L}^{-1}$. In the Lower Paraguay River (SS 12 and SS 13), the two populations studied during this fieldwork were living with $\mathrm{Ca}^{2+}$ concentrations of $2 \mathrm{mg} . \mathrm{L}^{-1}$. So, $\mathrm{Ca}^{2+}$ concentrations were found not to be limiting the establishment of L. fortunei populations (Table 2).

Rate of dispersal of exotic species depends on the spatial scale and may be accelerated or inhibited by human activities (Karatayev et al., 2007b). However, characterizing invasibility at a higher hierarchic scale without correctly determining the characteristics of the immediately lower hierarchy - or the invasiveness of the species could lead to erroneous interpretations. It is unwise, for instance, to jump to a regional scale without precise data on the invasibility of local or smaller unit scales, as this renders incorrect predictions on the dispersion of the invading species. As a consequence, environments in which invasion is virtually impossible (even with man as a vector) may be taken to be potentially prone to invasion. This scenario may become real when input data used for modeling a potential distribution of $L$. fortunei include (a) inaccurate or incorrect invasiveness characteristics (e.g., a higher salinity tolerance) and (b) incorrect invasibility data. This would happen if one considered that these data are theoretical characteristics of the spatial scale under study, without knowing the characteristics of the lower scales that make up that higher spatial hierarchy (e.g., lower saline concentration, lower sediment load, or the existence of temporary water bodies). Because L. fortunei exhibits a jump-dispersal mechanism (Boltovskoy et al., 2006), it could potentially settle upstream of its present range. However, because of the physical and chemical barriers described herein, the species is restricted to the environmentally favorable locations, but does not invade others that - because similar at a regional scale - theoretically could be susceptible to invasion.

Countries are attempting to control the rate of new biological invasions and need better ways of assessing the risks and benefits of introductions. In this sense, invasion models are tools for successfully predicting invasive species (Caley et al., 2006). Interactions within an invasion process can be analyzed by means of simulations, considering an input of species and habitat features which will render an output of risk and invasion rates patterns. The advantage of modelling the potential distribution is that the possibility of an invasion can be assessed before the actual introduction of a species occurs (Peterson and
Vieglais, 2001). To reach reliable predictions, the model should be fed with accurate environmental data. According to MacIsaac et al. (2001), full use of pre- and post-invasion datasets (where they exist) is necessary to test concepts emerging from the models. In this paper, we present a detailed description of the factors limiting the dispersion of L. fortunei.

The results presented herein allow the prediction of the geographic expansion of L. fortunei in river systems, based on physical and chemical variables. These variables are not commonly used in regional-scale models (Oliveira et al., 2010a). The findings of this study may be useful for the management of invasive species not only in the Andean tributaries of the Paraná and Paraguay rivers but also in other environments it may invade (Sousa et al., 2006). Likewise, the data and results obtained can be used to prevent the invasion by the golden mussel into susceptible regions (the rest of America and Western Europe).

Acknowledgements. The present work was partially funded by Committee Research and Exploration-National Geographic Society (Grant 7824-05) as well as by FCNyM (UNLP), ANPCyT (Pict 25621) and CONICET (PIP 1017). We thank M. Lagreca (Comisión de Investigaciones Cientificas-CIC, Bs.As.) for technical support and INALI (CONICET-UNL) for logistic field support.

\section{References}

Amarilla M.E. and Amsler M.L., 2005. Evaluación del transporte de sedimentos en el tramo medio del río Pilcomayo. In: XX Congreso Nacional del Agua, Mendoza, Argentina (in CD-ROM).

Amsler M. and Drago E.C., 1999. A review of the suspended sediment budget at the confluence of the Paraná and Paraguay River. In: HiBAm (ed.), Proceedings of the International Symposium "Hydrological and Geochemical Processes in Large Scale River Basins", Manaus, Brazil (in CD-ROM).

Angonesi L.G., Rosa N.G. and da Bemvenuti C.E., 2008. Tolerance to salinities shocks of the invasive mussel Limnoperma fortunei under experimental conditions. Iheringia Sér Zool., 98, 66-99.

APHA, 1985. Standard methods for examination of water and waste-water (16th edn.), American Public Health Association, New York.

Barbosa F.G. and Melo A.S., 2009. Modelo preditivo de sobrevivência do Mexilhão Dourado (Limnoperna fortunei) em relação a variações de salinidade na Laguna dos Patos, RS, Brasil. Biota Neotrop., 9, 407-412.

Benda L., Poff N.L., Miller D., Dunne T., Reeves G., Pess G. and Pollock M., 2004. The network dynamics hypothesis: how channel networks structure riverine habitats. BioScience, 54, 413-427.

Boltovskoy D., Correa N., Cataldo D. and Sylvester F., 2006. Dispersion and ecological impact of the invasive freshwater bivalve Limnoperna fortunei in the Río dela Plata watershed and beyond. Biol. Invasions, 8, 947-963. 
Bonetto A.A., 1994. Austral rivers of South America. In: Margalef R. (ed.), Limnology now: a paradigm of planetary problems, Elsevier Science B.V., Amsterdam, 425-472.

Caley P., Lonsdale W.M. and Pheloung P.C., 2006. Quantifying uncertainty in predictions of invasiveness, with emphasis on weed risk assessment. Biol. Invasions, 8, 1595-1604.

Capítoli R.R. and Bemvenuti C.E., 2004. Distribuição do mexilhão dourado Limnoperna fortunei (Dunker, 1857) na área estuarina da Lagoa dos Patos e Canal São Gonçalo. Anais do VI Simpósio de Ecossistemas Brasileiros, Publ. ACIESP, 110, 98-107.

Capítoli R.R., Colling L.A. and Bemvenuti C.E., 2008. Cenários de distribuição do mexilhão dourado Limnoperna fortunei (Mollusca - Bivalvia) sob distintas condições de salinidade no complexo lagunar Patos-Mirim, RS - BRASIL. Atlântica, $30,35-44$.

Carlton J.T., 1996. Pattern, process, and prediction in marine invasion ecology. Biol. Conserv., 78, 97-106.

Choi S.S. and Kim J.S., 1985. Studies on the metamorphosis and the growth of larva in Limnoperna fortunei. Korean $J$. Malacol., 1, 13-18.

Choi S.C. and Shin C.N., 1985. Study on early development and larvae of Limnoperna fortunei. Korean J. Malacol., 1, 5-12.

Claudi R. and Mackie G.L., 1994. Zebra Mussel Monitoring and Control, Lewis Publishers, Boca Raton, FL, 227 p.

Cordini R.I., 1947. Los ríos Pilcomayo en la Región del Patiño. Anales Dirección de Minas y Geología, 1, 83.

Darrigran G., 2002. Potential impact of filter-feeding invaders on temperate inland freshwater environments. Biol. Invasions, 4, 145-156.

Darrigran G., 2010. Summary of the distribution and impact of the golden mussel in Argentina and neighboring countries. In: Claudi R. and Mackie G. (eds.), Practical Guide for the Monitoring and Control of Aquatic Invasive Molluses in Freshwater Systems, Taylor and Francis Group, LLC, CRC Press, Boca Raton, FL, 389-396.

Darrigran G. and Damborenea C., 2005. A bioinvasion history in South America: Limnoperna fortunei (Dunker, 1857), the golden mussel. Amer. Malac. Bull., 20, 105-112.

Darrigran G. and Damborenea C., 2006. Aspectos generales vinculados a la prevención y control. In: Darrigran G. and Damborenea C. (eds.), Bioinvasión del mejillón dorado en el continente americano, Edulp, La Plata, 153-165.

Darrigran G. and Damborenea C., 2011. Ecosystem engineering impact of Limnoperna fortunei in South America. Zool. Sci., $28,1-7$.

Darrigran G. and Ezcurra de Drago I., 2000. Invasion of the exotic freshwater mussel Limnoperna fortunei (Dunker, 1857) (Bivalvia: Mytilidae) in South America. Nautilus, 114, 69-73.

Darrigran G.A. and Pastorino G., 2004. Distribution of the golden mussel Limnoperna fortunei (Dunker, 1857) (Family Myilidae) after 10 years invading. Am. J. Conch. Spec. Publ., $3,95-101$.

Darrigran G., Damborenea C., Penchaszadeh P. and Taraborelli C., 2003. Adjustment of Limnoperna fortunei (Bivalvia: Mytilidae) after ten years of invasion in the Americas. J. Shellfish Res., 22, 141-146.

Darrigran G., Maroñas M. and Colautti D., 2004. Air exposure as a control mechanism for the "golden mussel" Limnoperna fortunei (Dunker, 1857) (Bivalvia, Mytilidae). J. Fresh Ecol., 19, 461-464.
Darrigran G., Damborenea C. and Greco N., 2007. Freshwater invasive bivalves in man-made environments: a case study of larvae biology of Limnoperna fortunei in a Hydroelectric Power Plant in South America. Ambio, 36, 575-579.

Davis M.A., 1999. Invasion Biology, Oxford University Press, New York, 244 p.

Deaton L., Derby J., Subhedar N. and Greenberg M., 1989. Osmoregulation and salinity tolerance in two species of bivalve mollusc: Limnoperna fortunei and Mytilopsis leucophaeta. J. Exp. Mar. Biol. Ecol., 133, 67-79.

dos Santos C.P., Mansur M.C.D. and Würdig N.L., 2008. Variações no comprimento dos indivíduos de uma população do mexilhão dourado, Limnoperna fortunei (Mollusca: Bivalvia: Mytilidae), ao longo do ano, na Praia do Veludo, Lago Guaíba, Rio Grande do Sul, Brasil. Rev. Bras. Zool., 25, 389-396.

Drago E.C. and Amsler M.L., 1988. Suspended sediment at a cross section of the Middle Paraná River: concentration, granulometry and influence of the main tributaries. Sediment Budgets IAHS Publ., 174, 381-396.

Drago E.C. and Paira A., 1997. Situación geohidrográfica del río Salado del Norte y estructura física de los principales subcuencas de su tramo inferior. In: Drago E.C. (ed.), Conservación y manejo de ecosistemas acuáticos continentales: contaminación y acuacultura, Proyecto PID-BID (Período 1993-1996), Instituto Nac. de Limnología (INALI-CONICET), Santo Tomé, 12-69.

Drago E.C. and Quirós R., 1996. The hydrochemistry of the inland waters of Argentina: a review. Int. J. Salt Lake Res., 4, 315-325.

Emerton L. and Howard G., 2008. A Toolkit for the Economic Analysis of Invasive Species, Global Invasive Species Programme, Nairobi, $100 \mathrm{p}$.

EVARSA, 2000. Estadística hidrológica del Siglo XX, República Argentina, Evaluación de Recursos S. A. (EVARSA), Buenos Aires, 291 p.

Ezcurra de Drago I., Montalto L. and Oliveros O., 2006. Desarrollo y ecología larval de Limnoperna fortunei. In: Darrigran G. and Damborenea C. (eds.), Bioinvasión del mejillón dorado en el continente americano, Edulp, La Plata, 83-91.

Frissel C.A., Warren W.J. and Hurley M.D., 1986. A hierarchical framework for stream habitat classification: Viewing streams in a watershed context. Environ. Manage., 10, 199214.

Gonçalves A.M.M., Castro B.B., Pardal M.A. and Gonçalves F., 2007. Salinity effects on survival and life history of two freshwater cladocerans (Daphnia magna and Daphnia longispina). Ann. Limnol. - Int. J. Lim., 43, 13-20.

Goniadzki D., Vila D., Uriburu M., Almeira G., Calvo D. and Rodríguez D., 2007. Río Pilcomayo, Informe de situación por crecida extraordinaria, Instituto Nacional del Agua (INA), Buenos Aires, 5 p.

Haines A., Finlayson B. and McMahon T.A., 1988. A global classification of river regimes. Appl. Geography, 8, 255-272.

Hammer Ø., Harper D.A.T. and Ryan P.D., 2001. PAST: paleontological statistics software package for education and data analysis. Palaeontol. Electron., 4, 9 p.

IUCN, 2000. Guidelines for the prevention of biodiversity loss caused by alien invasive species, 51st Meeting IUCN Council, Gland. 
Karatayev A.Y., Padilla D.K., Minchin D., Boltovskoy D. and Burlakova L.E., 2007a. Changes in global economies and trade: the potential spread of exotic freshwater bivalves. Biol. Invasions, 9, 161-180.

Karatayev A.Y., Boltovskoy D., Padilla D.K. and Burlakova L.E., 2007b. The invasive bivalves Dreissena polymorpha and Limnoperna fortunei: parallels, contrasts, potential spread and invasion impacts. J. Shellfish Res., 26, 205-213.

Kluza D.A. and McNyset K.M., 2005. Ecological niche modeling of aquatic invasive species. Aquat. Invaders, 16, 1-7.

MacIsaac H.J., Grigorovich I.K. and Ricciardi A., 2001. Reassessment of species invasions concepts: the Great Lakes basin as a model. Biol. Invasions, 3, 405-416.

Marçal S.F. and Callil C.T., 2008. Structure of invertebrates community associated with Eichhornia crassipes Mart. (Solms-Laubach) after the introduction of Limnoperna fortunei (Dunker, 1857) (Bivalvia, Mytilidae) in the Upper Paraguay River, MT, Brazil. Acta Limnol. Bras., 20, 359-371.

Marco D., Páez S. and Cannas S., 2002. Species invasiveness in biological invasion: a modeling approach. Biol. Invasions, 4, 193-205.

Martín Vide J.P., Amarilla M., Gamarra M. and Zárate F., 2007. Problema de sedimentación en el río Pilcomayo. In: Memorias III Simposio Regional sobre Hidráulica de Ríos, Córdoba, 10.

McGill B.J., Etienne R.S., Gray J.S., Marti D.A., Anderson J., Benecha H.K., Dornelas M., Enquist B.J., Green J.L., He F., Hurlbert A.H., Magurran A.E., Marquet P.A., Maurer B.A., Ostling A., Soykan C.U., Ugland K.I. and White E.P., 2007. Species abundance distributions: moving beyond single prediction theories to integration within an ecological framework. Ecol. Lett., 10, 995-1015.

Montalto L. and Ezcurra de Drago I., 2003. Tolerance to desiccation of an invasive mussel, Limnoperna fortunei (Dunker, 1857) (Bivalvia, Mytilidae), under experimental conditions. Hydrobiologia, 498, 161-167.

Morton B., 1977. The population dynamics of Limnoperna fortunei (Dunker 1857) (Bivalvia: Mytilacea) in Plover Cove Reservoir, Hong Kong. Malacologia, 16, 165-182.

Oliveira M.D., Takeda A.M., Barros L.F., Barbosa D.S. and Resende E.K., 2006. Invasion by Limnoperna fortunei (Dunker, 1857) (Bivalvia Mytilidae) of the Pantanal wetland, Brazil. Biol. Invasions, 8, 97-104.

Oliveira M., Hamilton S. and Jacobi C., 2010a. Forecasting the expansion of the invasive golden mussel Limnoperna fortunei in Brazilian and North American rivers based on its occurrence in the Paraguay River and Pantanal wetland of Brazil. Aquat. Invasions, 5, 59-73.

Oliveira M.D., Hamilton S.K., Calheiros D.F. and Jacobi C.M., 2010b. Oxygen depletion events control the invasive golden mussel (Limnoperna fortunei) in a Tropical Floodplain. Wetlands, 30, 705-716.

Oliveira M.D., Calheiros D.F., Jacobi C.M. and Hamilton S.K., 2011. Abiotic factors controlling the establishment and abundance of the invasive golden mussel Limnoperna fortunei. Biol. Invasions, 13, 717-729.

Orenzans J., Schwindt E., Pastorino G., Bortulus A., Casas G., Darrigran G., Elias R., Lopez Gappa J.J., Obenet S.,
Pascual M., Penchaszadeh P., Piriz M.L., Sacarbino F., Spivak E.D. and Vallarino E.A., 2002. No longer a pristine confine of the World Ocean - A survey of exotic marine species in the Southwestern Atlantic. Biol. Invasions, 4, 115-143.

Pastorino G., Darrigran G.A., Martin S.M. and Lunaschi L., 1993. Limnoperna fortunei (Dunker, 1857) (Mytilidae), nuevo Bivalvo invasor en aguasdel Río de la Plata. Neotropica, 39, 34.

Peterson A.T. and Vieglais D.A., 2001. Predicting species invasions using ecological niche modeling: new approaches from bioinformatics attack a pressing problem. Bioscience, 51, 363-371.

Poff N.L., 1997. Landscape filters and species traits: towards mechanistic understanding and prediction in stream ecology. J. North. Am. Benthol. Soc., 16, 391-409.

Rahel F.J., 2002. Homogenization of freshwater faunas. Аnnu. Rev. Ecol. Syst., 33, 291-315.

Ramcharan C.W., Padilla D.K. and Dodson S.I., 1992. Models to predict potential occurrence and density of the zebra mussel, Dreissena polymorpha. Can. J. Fish. Aquat. Sci., 49, 2611-2620.

Ricciardi A., 1998. Global range expansion of the Asian mussel Limnoperna fortunei (Mytilidae): another fouling threat to freshwater systems. Biofouling, 13, 97-106.

Roche M.A., Guyot J.L., Calle H., Cortes J., Pereira M. and Rodriguez H., 1989. Erosión, balance de sedimentos y materias disueltas en la cuenca alta del río Paraguay (ríos Pilcomayo y Bermejo, Bolivia). In: IV Congreso Nacional de Ingeniería Sanitaria y Ambiental, Simposio sobre preservación del medio ambiente, La Paz, 15-30.

Soldano F.A., 1947. Régimen y aprovechamiento de la Red Fluvial Argentina. Parte I: El río Paraná y sus tributarios, Cimera, Buenos Aires, 277 p.

Sousa R., Antunes C. and Guilhermino L., 2006. Factors influencing the occurrence and distribution of Corbicula fluminea (Müller, 1774) in the River Lima estuary. Ann. Limnol. - Int. J. Lim., 42, 165-171.

Sprung M., 1987. Ecological requirements of developing Dreissena polymorpha eggs. Archiv. Hydrobiol. Suppl., 79, 69-86.

UNL, 2005. Vulnerabilidad de los Recursos Hídricos en el Litoral - Mesopotamia T.1. Argentina. Actividades Habilitantes para la $2^{\mathrm{a}}$ Comunicación Nacional del Gobierno de la República Argentina a las partes de la Convención Marco de las Naciones Unidas sobre Cambio Climático, TF 51287/ar, UNL, Facultad de Ingeniería y Ciencias Hídricas. http://aplicaciones.medioambiente.gov. ar/archivos/web/UCC/File/comunicaciones_nacionales/unl_ tomo1.pdf.

Vinogradov G.E., Smirnova N.F., Sokolov V.A. and Bruznitsky A.A., 1993. Influence of chemical composition of the water on the mollusk Dreissena polymorpha. In: Nalepa T.F. and Schloesser D.W. (eds.), Zebra Mussel: Biology, Impact, and Control, Lewis Publishers, Boca Raton, FL, 283-294.

Williams W.D., 1981. Inland salt lakes: an introduction. Hydrobiologia, 81/82, 1-14. 